\title{
Neonatal Transfer Rate and Mode of Delivery from 37th Week of Gestation in a German Perinatal Center Level 1
}

\section{Neonatale Verlegungsrate und Entbindungsmodus ab der 37. Schwangerschaftswoche in einem deutschen Perinatalzentrum Level 1}

Authors

Affiliations
J. Reinhard ${ }^{1}$, L. Hanker ${ }^{2}$, N. Sänger ${ }^{2}$, J. Yuan ${ }^{2}$, F. Louwen ${ }^{2}$

1 St. Marienkrankenhaus Frankfurt, Frankfurt am Main

${ }^{2}$ Johann Wolfgang Goethe-Universität Frankfurt am Main, Klinik für Frauenheilkunde und Geburtshilfe, Frankfurt am Main

\section{Key words}

- mode of delivery

(caesarean section, forceps, vaginal delivery)

- vaginal breech delivery

twin

term neonate

- transfer rate to neonatal intensive care

Schlüsselwörter

- Entbindungsmodus (Sectio, Forzeps, Spontanpartus)

- vaginale Beckenendlagen-Entbindung

- Gemini

- reife Neugeborene

- Verlegungsrate

\section{received 28.6.2012 \\ revised $\quad 5.2 .2013$ \\ accepted 6.3.2013}

Bibliography

DOI http://dx.doi.org/

10.1055/s-0032-1328435

Geburtsh Frauenheilk 2013; 73 :

324-329 @ Georg Thieme

Verlag KG Stuttgart · New York . ISSN 0016-5751

\section{Correspondence}

\section{Priv. Doz. Dr. med. Joscho} Reinhard, MBBS BSc(Hon)

St. Marienkrankenhaus Frankfurt

Richard-Wagner Straße 14

60318 Frankfurt am Main

J.Reinhard@katharina-kasper.de

\section{Abstract}

$\nabla$

Introduction: Rates for caesarean section are on the rise and the reasons for this are being discussed worldwide. As the data is unclear, the identification of additional predictive factors for caesarean section is important as caesarean sections are closely linked to maternal and neonatal morbidity. The aim of the study was to identify predictive factors for the transfer of the neonate to a neonatal intensive care unit (NICU) depending on the mode of delivery. The study investigated the neonatal transfer rates for singleton and twin pregnancies delivered at $\geq 36+0$ weeks of gestation.

Material and Methods: The data of all singleton $(\mathrm{n}=4181)$ and twin pregnancies $(\mathrm{n}=305$ neonates), delivered between 1 January 2009 and 31 March 2012 in the OB/Gyn Department of the University Hospital Frankfurt/M, Germany, (perinatal center level 1) were evaluated. The indications for transfer to the NICU and possible predictive factors were evaluated.

Results: Our study found a two times lower neonatal transfer rate for vaginal deliveries of pregnant women without risk factors compared to women with risk factors. The following neonatal transfer rates to the NICU were noted for singleton pregnancies: $4.7 \%$ without risk factors, $8.3 \%$ high-risk pregnancy, $6.2 \%$ vaginal breech delivery, $9.3 \%$ forceps delivery, $10 \%$ elective primary caesarean section and $14 \%$ secondary caesarean section. There was a statistically significant correlation between gestational age and transfer to the NICU (rho 0.11; p < 0.001). Similarly, a correlation was also found for mode of delivery (0.12; $\mathrm{p}<0.001), 5$ minute APGAR score $(0.24$; $\mathrm{p}<0.001), 10$ minute APGAR score (0.34; $\mathrm{p}<0.001)$ and birth weight $(0.12 ; \mathrm{p}<0.001)$. Conclusion: Vaginal delivery resulted in a lower rate of neonatal transfers compared to caesarean section and the difference was statistically signif-

\section{Zusammenfassung \\ $\nabla$}

Einleitung: Die steigende Sectio-Rate wird weltweit diskutiert. Aufgrund der unklaren Datenlage scheint die Identifikation weiterer prädiktiver Faktoren, um die Indikation für eine Sectio zu stellen, sinnvoll und nötig, da diese eng mit mütterlicher und kindlicher Morbidität verbunden ist. In dieser Studie wird versucht, die Verlegungsrate auf die neonatologische Intensivstation von Neugeborenen ( $\geq 36+0$ SSW) durch den Entbindungsmodus vorherzusagen. Außerdem wird nach Faktoren gesucht, die die Wahrscheinlichkeit einer Verlegung beeinflussen.

Material und Methode: Die Daten aller Einlings( $n=4181) \quad$ und Zwillingsschwangerschaften ( $n=305$ Neugeborene), die zwischen dem 1. Januar 2009 und dem 31. März 2012 in der Universitätsfrauenklinik Frankfurt am Main entbunden wurden, wurden ausgewertet. Die Indikation der Verlegung auf die neonatologische Intensivstation sowie mögliche prädiktive Faktoren wurden evaluiert.

Ergebnisse: In unserer Studie zeigte sich bei Vaginalgeburten von Schwangeren ohne Risikofaktoren eine fast 2-fach niedrigere neonatale Verlegungsrate im Vergleich zu Risikoschwangeren. Die folgenden Verlegungsraten wurden bei Einlingsschwangerschaften detektiert: 4,7\% ohne Risikofaktoren, 8,3\% Risikoschwangerschaft, 6,2\% vaginale Beckenendlagen-Entbindungen, 9,3\% Forzeps-Entbindung, $10 \%$ primäre Sectio und $14 \%$ sekundäre Sectio. Es zeigte sich eine signifikante Korrelation der Schwangerschaftswoche mit der Verlegungsrate in die Kinderklinik (Rho $0,11 ; p<0,001)$. Außerdem zeigten sich weitere Korrelationen mit dem Entbindungsmodus $(0,12$; $\mathrm{p}<0,001)$, 5-Minuten-APGAR $(0,24 ; \mathrm{p}<0,001)$, 10-Minuten-APGAR $(0,34 ; \mathrm{p}<0,001)$ und Geburtsgewicht $(0,12 ; \mathrm{p}<0,001)$.

Schlussfolgerung: Die vaginale Entbindung zeigte eine statistisch signifikant niedrigere Rate an 
icant. Gestational age had a statistically significant impact on the transfer rate. neonatalen Verlegungen im Vergleich zur Sectio. Das Schwangerschaftsalter hat einen statistisch signifikanten Einfluss auf die Verlegungsrate.

\section{Introduction}

Rates for caesarean section are on the rise and the reasons for this increase are being discussed worldwide. Many causative factors have already been identified; they include maternal choice of the mode of delivery [1,2], vaginal birth after prior caesarean section [3], and breech presentation [4]. Recent studies have particularly focussed on maternal and neonatal morbidity [1,2,4-7]. Some studies have recommended elective primary caesarean section to reduce the "fear of giving birth" [8], decrease incontinence problems post partum [9] and reduce the risks associated with breech presentation [4]. Other studies have concluded that vaginal birth should be recommended because of the associated lower maternal mortality rate [10], shorter convalescence time [11], lower rate of intrauterine foetal deaths in later pregnancies [3], and lower rate of neonatal adjustment disorders [5, 12-15]. As the data appear to be unclear, the identification of additional predictive factors for caesarean section is important and necessary, as caesarean section is closely linked to maternal and neonatal morbidity.

This study aimed to predict the transfer rate to the neonatal intensive care unit (NICU) for neonates (born at $\geq 36+0$ weeks of gestation) based on the mode of delivery. In addition, the study investigated factors which affected the probability of a transfer to the NICU.

\section{Material and Methods}

All singleton $(\mathrm{n}=4181)$ and twin pregnancies $(\mathrm{n}=305)$ delivered at $\geq 36+0$ weeks of gestation between 1 January 2009 and 31 March 2012 in the OB/Gyn Department of Johann Wolfgang Goethe University Hospital in Frankfurt (certified level 1 perinatal center) were analysed retrospectively ( $\bullet$ Fig. 1 ). All pregnant women included in the study were selected using the birth documentation system GeDoWin Geburt@ (version 13.04); the criterion for inclusion in the study was $\geq 36+0$ weeks of gestation; the exclusion criterion was intrauterine foetal death, triplet, quadruplet. The week of gestation was calculated using the date of the last menstruation or the ultrasound investigation done in the 1st trimester. The decision for operative vaginal delivery was done in accordance with the DGGG guideline on operative vaginal deliveries [18]. The definition of a high-risk pregnancy was based on the definition given in the Mutterpass, the record issued in Germany to every pregnant woman by her doctor containing medical information relating to the individual woman's pregnancy.

Reasons for transfer of the neonate to the NICU were evaluated based on the diagnoses recorded in the GeDoWin Geburt $\odot$. Reasons for transfer are defined in the section on quality management in the guideline on the medical care of neonates. A paediatrician was consulted if any of the neonatal disorders listed below were present, and the paediatrician was responsible for initiating

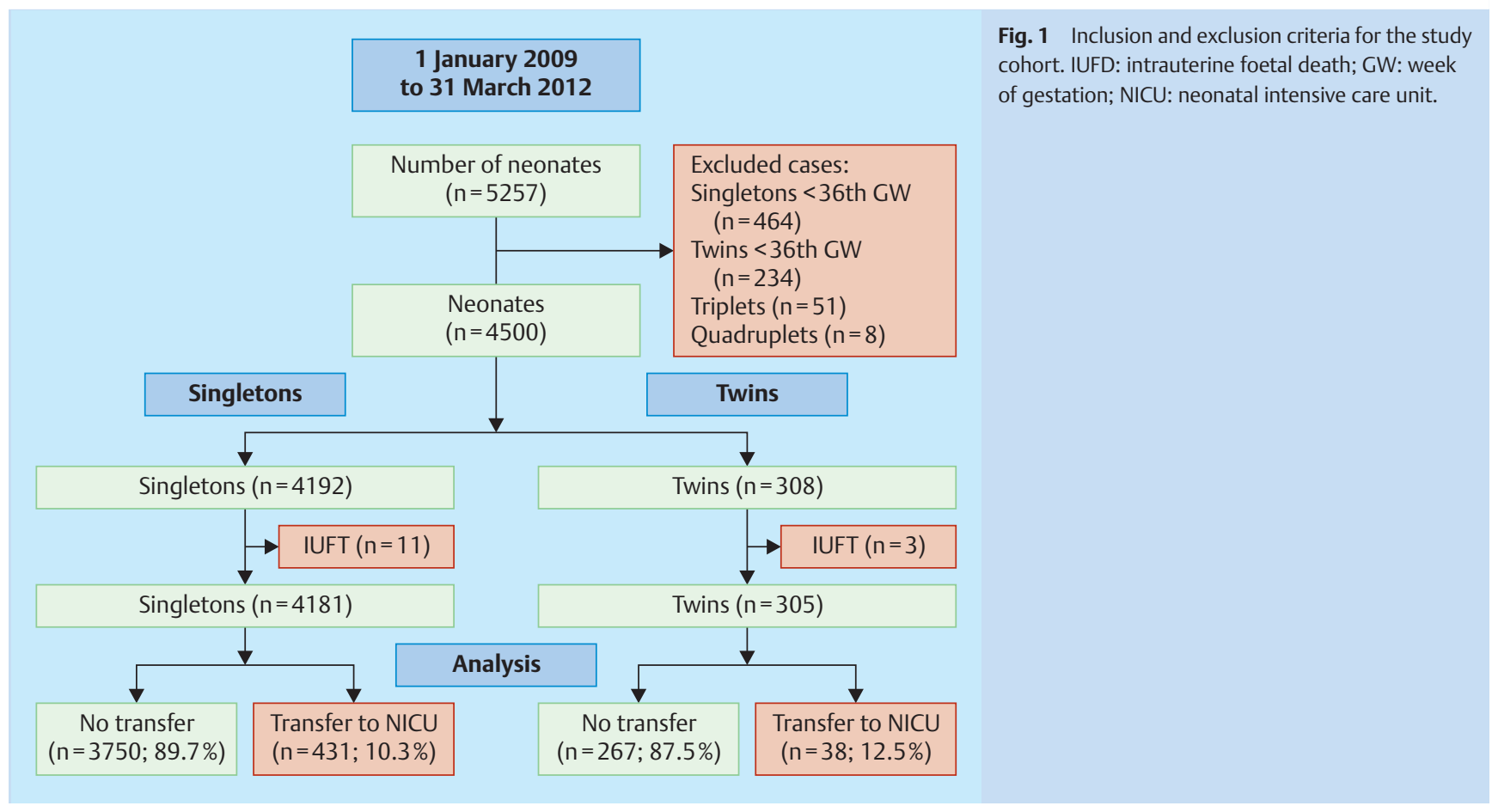


all further diagnostic steps and transfer to the NICU where indicated.

- Respiratory disorders (tachypnea, dyspnea, cyanosis)

- Jaundice

- Anamnestic indications of neonatal infection (maternal fever $>38.5^{\circ} \mathrm{C}$, maternal leukocytosis, maternal CRP concentrations $>4 \mathrm{mg} / \mathrm{dL}$, premature rupture of membranes (> 24 hours), prenatal vaginal smear (e.g. group B Streptococci in the anogenital area), peripartal maternal antibiotic administration, green amniotic fluid)

- Dystrophic neonate

- Birth weight $<$ 3rd percentile

- Neonatal hypoglycaemia (1-24 hours of life: blood sugar "dipstick" test <35 mg/dL; > 24 hours of life: blood sugar "dipstick" test $<45 \mathrm{mg} / \mathrm{dL}$ )

- Birth weight $>4000 \mathrm{~g}$ (fasting blood sugar level 2-times per day over a period of 3 days)

- Maternal HIV infection

- Cardiac arrhythmia

- Neonatal withdrawal symptoms/known maternal history of drug use

- Perinatal asphyxia (no generally authoritative definition; indications include: umbilical artery $\mathrm{pH}<7.10$, Apgar score (slight asphyxia=1 minute score 4-7; severe asphyxia=1 minute score $0-3$ ), ventilation for several minutes or intubation because the neonate is not breathing independently

- Congenital malformations

- Known maternal metabolic disorder/coagulopathy

The following potential influencing or predictive factors for a transfer to the neonatal intensive care unit of the Johann Wolfgang Goethe University Hospital Frankfurt were evaluated: duration of the birth, BMI, maternal age, gestational diabetes, mode of delivery, umbilical artery $\mathrm{pH}$, Apgar scores, sex of the baby, neonatal birth weight and length, pregnancy which exceeded due date, nuchal cord/umbilical cord entanglement, protracted birth (no progress in the birth for more than 2 hours), breech presentation, prior caesarean section, maternal fever during delivery, pathological CTG, and green amniotic fluid. The data were imported retrospectively into SPSS (Statistical Package for the Social Sciences Version 17.0, IBM, Ehningen) from the perinatal records. SPSS was used to calculate mean values, standard deviations, Spearman's rho coefficient, and analysis was done using Fisher's exact test, Mann-Whitney U-test and binary logistic regression analysis. Regression analysis was used to calculate the correlation between the predicted neonatal transfer and the factors "week of gestation" and "mode of delivery".
Table 1 Indication for neonatal transfer: comparison of singleton and twin pregnancies (Fisher's exact test).

\begin{tabular}{|c|c|c|c|}
\hline & Singleton & Twin & p-value \\
\hline HIV & $31(0.8 \%)$ & $0(0 \%)$ & n.s. \\
\hline $\begin{array}{l}\text { Birth weight less than } \\
2500 \mathrm{~g}\end{array}$ & $33(0.9 \%)$ & $25(8.2 \%)$ & $<0.001$ \\
\hline Respiratory disorder & $75(2.0 \%)$ & $5(1.6 \%)$ & n.s. \\
\hline $\begin{array}{l}\text { Other infection (specific to } \\
\text { the perinatal period) }\end{array}$ & $116(3.1 \%)$ & $4(1.3 \%)$ & n.s. \\
\hline Cardiac arrhythmia & $19(0.5 \%)$ & $2(0.7 \%)$ & n.s. \\
\hline Neonatal jaundice & $35(0.9 \%)$ & $0(0 \%)$ & n.s. \\
\hline $\begin{array}{l}\text { Neonatal withdrawal } \\
\text { symptoms }\end{array}$ & $20(0.5 \%)$ & $0(0 \%)$ & n.s. \\
\hline $\begin{array}{l}\text { Severe asphyxia during } \\
\text { birth }\end{array}$ & $5(0.1 \%)$ & $0(0 \%)$ & n.s. \\
\hline $\begin{array}{l}\text { Metabolic disorder/ } \\
\text { coagulopathy }\end{array}$ & $18(0.5 \%)$ & $0(0 \%)$ & n.s. \\
\hline Congenital malformations & $61(1.6 \%)$ & $2(0.7 \%)$ & n.s. \\
\hline Other reasons & $7(0.2 \%)$ & $0(0 \%)$ & n.s. \\
\hline $\begin{array}{l}\text { Total number of transferred } \\
\text { neonates }\end{array}$ & $423(10.1 \%)$ & $38(12.5 \%)$ & n.s. \\
\hline $\begin{array}{l}\text { Total number not } \\
\text { transferred }\end{array}$ & $3750(89.9 \%)$ & $267(87.5 \%)$ & - \\
\hline
\end{tabular}

\section{Results \\ $\nabla$}

\section{Similar transfer rates for full-term singleton and twin pregnancies}

Overall, the transfer rates were similar for full-term singleton and twin pregnancies (10.1 vs. $12.5 \%$; p $>0.05$; $\bigcirc$ Table 1 ). Only the factor "birth weight 1500-2500 g" was statistically significantly higher for twin pregnancies. In singletons, the most common reason (3.0\%) for transfer to the neonatal intensive care unit was an infection specific to the perinatal period, followed by adjustment disorders in $1.9 \%$ of neonates ( Table $\mathbf{1}$ ).

\section{Neonatal transfer rates depending}

on the mode of delivery

- Fig. 2 shows the mode of delivery for singleton and twin pregnancies in our study cohort. Pregnant women without risk factors had the lowest neonatal transfer rate with a rate of $4.7 \%$ after vaginal delivery. The neonatal transfer rate for high-risk pregnant women was almost twice as high at $8.3 \%(\mathrm{p}<0.001)$ ( Table 2 ). In comparison, spontaneous vaginal breech delivery was associated with a not statistically significant, minimally increased neonatal transfer rate of $6.2 \%$ ( $p>0.05)$. Forceps delivery and elective and secondary caesarean section resulted in higher neonatal transfer rates of 9.3, 10.0 (without malformations) and $14.0 \%$, re-

Table 2 Neonatal transfer rates depending on the mode of delivery for singleton pregnancies (comparison of delivery after normal pregnancy [no high-risk pregnancy] with high-risk pregnancy, forceps delivery, vaginal breech delivery and caesarean section); (Fisher's exact test).

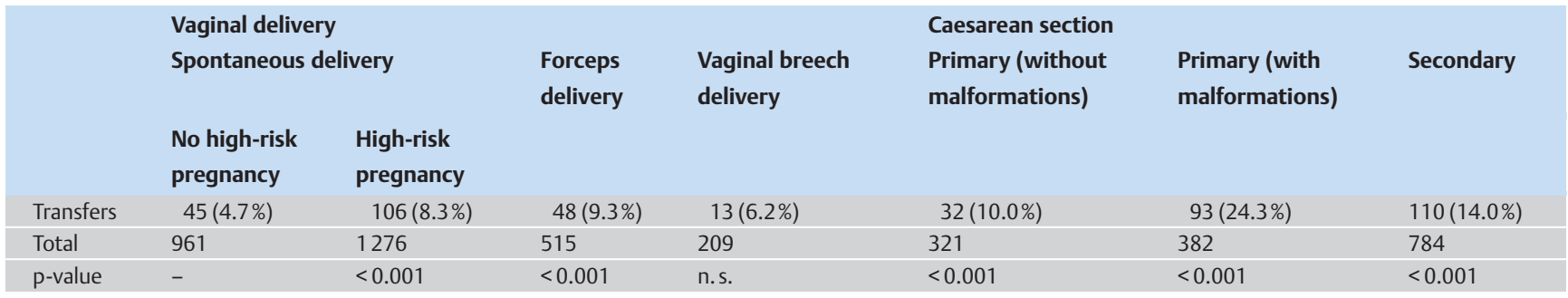



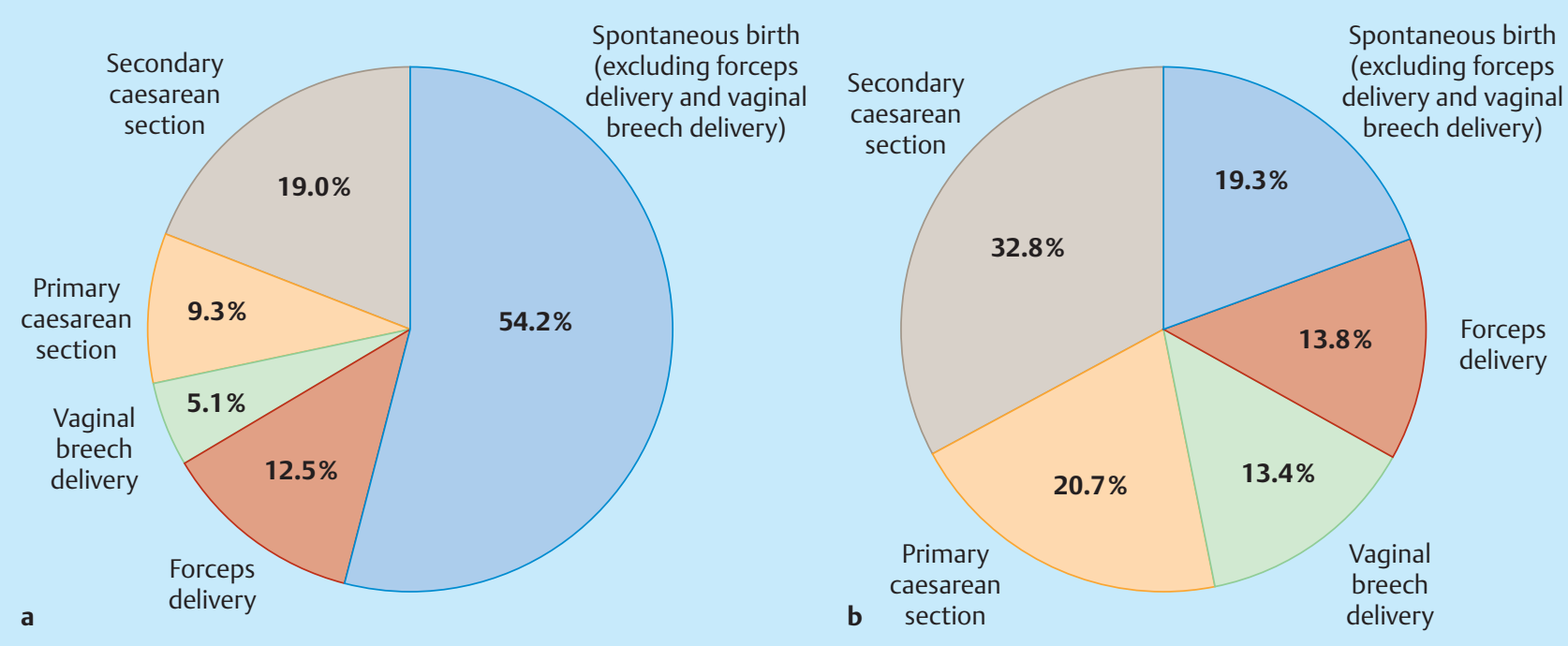

Fig. 2 a and $\mathbf{b}$ Mode of delivery for a singleton pregnancies $(n=4181)$ and $\mathbf{b}$ twin pregnancies $(n=305)$ born at $\geq 36+0$ weeks of gestation.

spectively, and these higher rates were statistically significant $(\mathrm{p}<0.001)$.

In high-risk pregnant women, only primary and secondary caesarean section resulted in a statistically significantly higher neonatal transfer rate $(\mathrm{p}<0.001)$ ( Table 2 ).

The neonatal transfer rates for twin pregnancies were similar to those of singleton pregnancies; the difference was not statistically significant.

\section{Neonatal transfer rate depending on gestational age}

- Table 3 and Fig. 3 a show neonatal transfer rates depending on the mode of delivery. A significant correlation was found between week of gestation and transfer to the neonatal intensive care unit (rho 0.11; $\mathrm{p}<0.001$ ). Transfer to the NICU was also found to be correlated to the mode of delivery $(0.12 ; \mathrm{p}<0.001)$, 5 minute Apgar score (0.24; $\mathrm{p}<0.001), 10$ minute Apgar score
(0.34; $\mathrm{p}<0.001)$, birth weight $(0.12 ; \mathrm{p}<0.001)$, neonatal length $(0.09 ; \mathrm{p}<0.001)$, sex of the neonate $(0.03 ; \mathrm{p}=0.04)$ and arterial $\mathrm{pH}$ at birth $(0.03 ; \mathrm{p}=0.03)$. No statistically significant correlation was found for "duration of the birth", "base excess (BE)", "maternal BMI" and "gestational diabetes" ( $p>0.05$ ).

Logistic regression analysis of singleton pregnancies found "week of gestation" to be statistically significant (odds ratio $=0.8 ; 95 \% \mathrm{CI}$ 0.7-0.8; $\mathrm{p}<0.001$ ). Vaginal delivery had a significant negative predictive value for transfer to a NICU (odds ratio $=0.5 ; 95 \% \mathrm{CI}$ $0.4-0.8 ; \mathrm{p}=0.001$ ); in comparison, primary caesarean section had a significant positive predictive value for transfer to a NICU (odds ratio $=1.1 ; 95 \%$ CI 1.0-1.2; $\mathrm{p}=0.009$ ). Forceps delivery and secondary caesarean section had no significant predictive value for neonatal transfer $(p>0.05)$. Logistic regression analysis of twin pregnancies found no statistically significant predictive value.

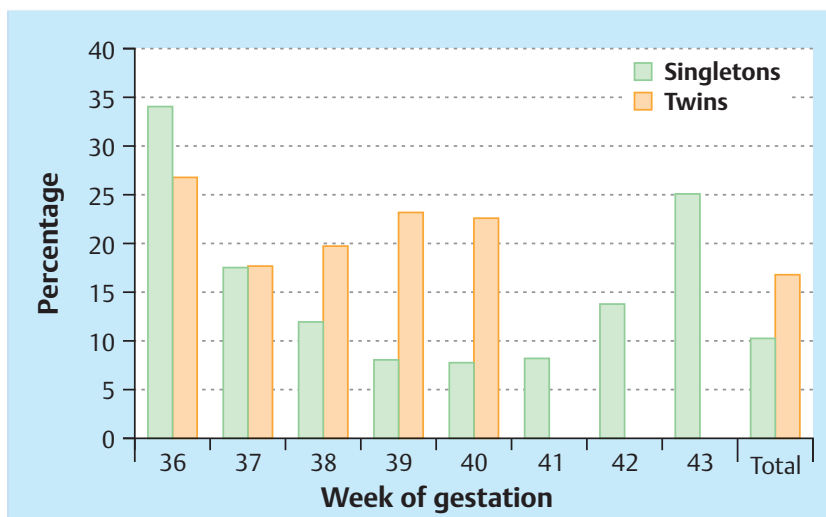

a

Fig. $\mathbf{3}$ a and $\mathbf{b}$ a Transfer rate of singleton pregnancies $(n=4181)$ and twin pregnancies born at $\geq 36+0$ weeks of gestation depending on gestational age. b Mode of delivery for singleton pregnancies (2009 $n=1255 ; 2010$ $n=1305 ; 2011 n=1292 ; 2012$ [1st quarter] $n=327$ ) depending on the year

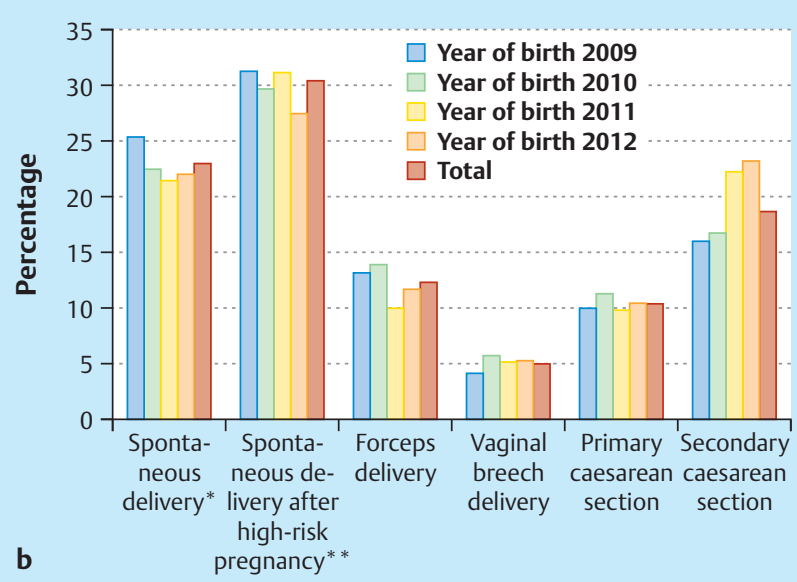

of birth and born at $\geq 36+0$ weeks of gestation; ${ }^{*}$ excluding forceps delivery, vaginal breech delivery and high-risk pregnancies; ${ }^{* *}$ excluding forceps delivery, vaginal breech delivery and non high-risk pregnancies. 
Table 3 Neonatal transfer rates depending on gestational age.

\begin{tabular}{|c|c|c|c|c|c|c|c|c|c|c|}
\hline & & \multicolumn{8}{|c|}{ Week of gestation } & \multirow[t]{2}{*}{ Total } \\
\hline & & 36 & 37 & 38 & 39 & 40 & 41 & 42 & 43 & \\
\hline \multirow[t]{2}{*}{ Singleton } & Transfer to NICU (\%) & 34 & 17.5 & 12 & 8.1 & 7.7 & 8.2 & 13.8 & 25 & 10.3 \\
\hline & Total $(n)$ & 147 & 314 & 643 & 1127 & 1257 & 624 & 65 & 4 & 4181 \\
\hline \multirow[t]{2}{*}{ Twin } & Transfer to NICU (\%) & 28.2 & 2.5 & 7.1 & 5.6 & 7.1 & & & & 11.1 \\
\hline & Total $(n)$ & 39 & 40 & 42 & 18 & 14 & & & & 153 \\
\hline \multirow[t]{2}{*}{ Twin (2nd) } & Transfer to NICU (\%) & 25.6 & 7.5 & 11.9 & 11.8 & 7.1 & & & & 13.8 \\
\hline & Total (n) & 39 & 40 & 42 & 17 & 14 & & & & 152 \\
\hline
\end{tabular}

$\mathrm{NICU}=$ neonatal intensive care unit

Mode of delivery depending on the year of birth

O Fig. $\mathbf{3} \mathbf{b}$ shows the mode of delivery depending on the year of birth. A comparison of the year 2009 with the year 2011 showed a highly significant increase in the rates of secondary caesarean sections $(\mathrm{p}<0.001)$ as well as a drop in the numbers of non-instrumental vaginal deliveries $(p=0.04)$ and of forceps deliveries $(p=0.02)$. No changes were found with respect to the rates of elective caesarean sections and of vaginal breech deliveries $(\mathrm{p}>0.05)$.

\section{Discussion \\ $\nabla$}

Our study found an almost two times lower rate of neonatal transfers to the neonatal intensive care unit for vaginal deliveries of pregnant women without risk factors compared to high-risk pregnant women.

Our results confirmed the findings of other studies [15,19-22] which showed that elective caesarean section was associated with a higher risk of neonatal respiratory difficulties compared to vaginal delivery or attempted vaginal delivery. If other impact factors such as malformations $[20,21,23]$ and high-risk pregnancies $[13,23]$ were excluded, the risk of neonatal respiratory distress was 2 to 3 times higher for planned caesarean sections compared to vaginal deliveries [21]. Some studies have reported even higher rates of respiratory distress in neonates delivered by caesarean section $[13,23]$.

Our results also confirm that gestational age had an important impact on adjustment disorders and neonatal transfer rates [5, $12-14,20-23]$. The scheduled date of the elective caesarean section should therefore be as close as possible to the due date. Some studies found that if the caesarean section was carried out prior to spontaneous onset of labour, this led to higher rates of neonatal respiratory distress $[5,14]$. Although anaesthetics and surgical procedures have become much safer, the rates for maternal and neonatal morbidity and mortality are higher compared to those reported for vaginal delivery [24]. As the mortality rate for vaginal delivery vs. caesarean section is now $1: 2.6$ (caesarean section mortality is $1: 57300)[25,26]$, the argument that maternal mortality is higher with caesarean section is becoming less and less important. However, the higher risk of morbidity specific to caesarean section remains (e.g. secondary healing), as does the increased probability for caesarean section, placentation disorder or uterine rupture with any subsequent pregnancy [26-28]. Although there are some studies on the complications of vaginal delivery, particularly urinary incontinence and faecal incontinence $[29,30]$, these complications require further studies and are not sufficient as an indication for caesarean section [31].
Our cohort did not reflect the increasing number of elective caesarean sections in recent years but showed instead a decrease in operative vaginal deliveries and an increase in secondary caesarean sections. Further studies will be necessary to determine whether this represents an objective trend or a subjective decision on the part of the midwife and the mother/parents, based on forensic considerations and a fear of neonatal complications with forceps delivery $[28,32,33]$.

\section{Conclusion}

As long as there are no contraindication(s) for a normal vaginal delivery of the full-term infant, vaginal delivery appears to be associated with a lower risk of neonatal transfer to a neonatal intensive care unit compared to elective caesarean section. If, however, elective caesarean section is necessary, then the date of the procedure should be scheduled to be as near as possible to the due date.

\section{Approval of the Ethics Committee}

The study was a retrospective analysis of clinical data which did not affect or change the management of the patients.

\section{Contributions of the Authors}

The first author designed the study, analysed the data and wrote the first draft of the manuscript. All of the authors evaluated the results and the manuscript.

\section{Conflict of Interest}

$\nabla$

None.

\section{References}

1 Grisaru S, Samuelo A. Primary nonmedically indicated cesarean section ("section on request"): Evidence based or modern vogue? Clin Perinatol 2004; 31: 409-430

2 Wax JR, Cartin A, Pinette MG et al. Patient choice cesarean: an evidencebased review. Obstet Gynecol Surv 2004; 59: 601-616

3 Smith GC, Pell JP, Dobbie R. Caesarean section and risk of unexplained stillbirth in subsequent pregnancy. Lancet 2003; 362: 1179-1184

4 Hannah ME, Hannah WJ, Hewson SA et al.; The Term Breech Trial Collaborative group. Planned caesarean section versus planned vaginal birth for breech presentation at term: a randomised multicentre trial. Lancet 2000; 356: 1375-1383 
5 Morrison JJ, Rennie JM, Milton PJ. Neonatal respiratory morbidity and mode of delivery at term: influence of timing of elective caesarean section. BJOG 1995; 102: 101-110

6 Häger R, Daltveit AK, Hofoss $D$ et al. Complications in cesarean deliveries: rates and risk factors. Am J Obstet Gynecol 2004; 190: 428-434

7 EckerJL. Once a pregnancy, always a cesarean? Rationale and feasibility of a randomized controlled trial. Am J Obstet Gynecol 2004; 190: 314318

8 Schindl M, Birner P, Reingrabner $M$ et al. Elective cesarean section vs. spontaneous delivery: a comparative study of birth experience. Acta Obstet Gynecol Scand 2003; 82: 834-840

9 Heit M, Mudd K, Culligan P. Prevention of childbirth injuries to the pelvic floor. Curr Womens Health Rep 2001; 1: 72-80

10 Harper MA, Byington RP, Espeland MA et al. Pregnancy-related death and health care services. Obstet Gynecol 2003; 102: 273-278

11 Bergholt T, Stenderup JK, Vedsted-Jakobsen A et al. Intraoperative surgical complications during cesarean section: an observational study of the incidence and risk factors. Acta Obstet Gynecol Scand 2003; 82: 251-256

12 Nicoll AE, Black C, Powls A et al. An audit of neonatal respiratory morbidity following elective caesarean section at term. Scott Med J 2004; 49: $22-25$

13 Zanardo V, Simbi AK, Franzoi $M$ et al. Neonatal respiratory morbidity risk and mode of delivery at term: influence of timing of elective caesarean delivery. Acta Paediatr 2004; 93: 643-647

14 Madar J, Richmond S, Hey E. Surfactant-deficient respiratory distress after elective delivery at "term". Acta Pædiatr 1999; 88: 1244-1248

15 Kolas T, Saugstad OD, Daltveit AK et al. Planned cesarean versus planned vaginal delivery at term: Comparison of newborn infant outcomes. Am J Obstet Gynecol 2006; 195: 1538-1543

16 Hübener C, Delius M, Deppe C et al. Entbindung versus Prolongation der Schwangerschaft - Bedeutung des Interleukin 6 im Fruchtwasser in der Entscheidungsfindung bei vorzeitiger Wehentätigkeit und V.a. Amnioninfektionssyndrom. Geburtsh Frauenheilk 2011; 71 - G_3

17 Reif P, Haas J, Schöll W et al. Reduktion der operativen Entbindungsrate durch den Einsatz von Mikroblutuntersuchungen bei auffälligem CTG unter Berücksichtigung des Gestationsalters. Geburtsh Frauenheilk 2011; 71 - P104

18 http://www.awmf.org/uploads/tx_szleitlinien/015-023_S1_Vaginaloperative_Entbindungen_12-2007_12-2012.pdf; last access: Feb. 2013

19 Zanardo V, Simbi AK, Franzoi $M$ et al. Neonatal respiratory morbidity risk and mode of delivery at term: influence of timing of elective caesarean delivery. Acta Paediatr 2004; 93: 643-647
20 Hansen $A K$, Wisborg $K$, Uldbjerg $N$ et al. Elective caesarean section and respiratory morbidity in the term and near-term neonate. Acta Obstet Gynecol 2007; 86: 389-394

21 van den Berg A, van Elburg RM, van Geijn HP et al. Neonatal respiratory morbidity following elective caesarean section in term infants - A 5year retrospective study and a review of the literature. Eur J Obstet Gynecol Reprod Biol 2001; 98: 9-13

22 Hales KA, Morgan MA, Thurnau GR. Influence of labor and route of delivery on the frequency of respiratory morbidity in term neonates. Int J Gynecol Obstet 1993; 43: 35-40

23 Levin EM, Ghai V, Barton JJ et al. Mode of delivery and risk of respiratory diseases in newborns. Obstet Gynecol 2001; 97: 439-442

24 Devendra K, Arulkumaran S. Should doctors perform an elective caesarean section on request? Ann Acad Med Singapore 2004; 32: 577-581

25 Absolute und relative Indikationen zur Sectio caesarea. AWMF 015 054 (S1); 2008. http://www.awmf.org/leitlinien/detail/11/015-054. html; last access: Feb. 2013

26 Welsch H, Wischnik A. Müttersterblichkeit. In: Schneider H, Husslein P, Schneider KTM, Hrsg. Die Geburtshilfe. 3. Auflage. Berlin: Springer Verlag; 2006: 1049-1063

27 Simoes E, Kunz SK, Münnich R et al. Informed consent for cesarean delivery: method-associated morbidity gradients require the participation of pregnant women. Geburtsh Frauenheilk 2010; 70: 732-738

28 Hübner $M$, Reisenauer $C$, Abele $H$. Welchen Stellenwert hat die primäre Sectio caesarea? Geburtsh Frauenheilk 2010; 70: 911-913

29 Gyhagen M, Bullarbo M, Nielsen TF et al. The prevalence of urinary incontinence 20 years after childbirth: a national cohort study in singleton primiparae after vaginal or caesarean delivery. BJOG 2012; DOI: 10.1111/j.1471-0528.2012.03301.x

30 Rath W, Vetter K. Der Kaiserschnitt zwischen Selbstbestimmungsrecht der Schwangeren, Mangel an gesichertem Wissen und ärztlicher Entscheidung. Geburtsh Frauenheilk 2002; 62: 838-842

31 Nelson RL, Fumer SE, Westercamp $M$ et al. Cesarean delivery for the prevention of anal incontinence. Cochrane Database Syst Rev 2010; 2 : CD006756

32 Reiter B, Windbichler G. Motive für den Wunsch nach einer electiven Sectio ohne medizinische Indikation. Geburtsh Frauenheilk 2010; 70: P28

33 Kunkel S, Schuler S, Bauer B et al. Gibt es Gründe für die steigende Sectiorate? Eine retrospektive Analyse der Sectiones 1995 und 2005 in der Missionsärztlichen Klinik in Würzburg. Geburtsh Frauenheilk 2012; 72: P33

Deutschsprachige Zusatzinformationen online abrufbar unter: www.thieme-connect.de/ejournals/toc/gebfra. 